\title{
Pakistan on the Brink: The Future of America, Pakistan, and Afghanistan. By Ahmed Rashid. New York, N.Y.: Viking, 2012.
}

Mark J. Roberts

Follow this and additional works at: https://digitalcommons.usf.edu/jss pp. 131-133

\section{Recommended Citation}

Roberts, Mark J.. "Pakistan on the Brink: The Future of America, Pakistan, and Afghanistan. By Ahmed Rashid. New York, N.Y.: Viking, 2012.." Journal of Strategic Security 5, no. 4 (2012) : 131-133.

DOI: http://dx.doi.org/10.5038/1944-0472.5.4.11

Available at: https://digitalcommons.usf.edu/jss/vol5/iss4/5

This Book Review is brought to you for free and open access by the Open Access Journals at Digital Commons @ University of South Florida. It has been accepted for inclusion in Journal of Strategic Security by an authorized editor of Digital Commons @ University of South Florida. For more information, please contact digitalcommons@usf.edu. 
Pakistan on the Brink: The Future of America, Pakistan, and Afghanistan. By Ahmed Rashid. New York, N.Y.: Viking, 2012. 


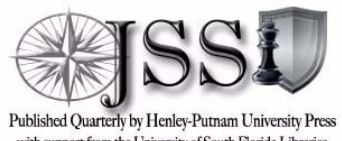

Published Quartily by Henley-Putnam University Press

Pakistan on the Brink: The Future of America, Pakistan, and Afghanistan. By Ahmed Rashid. New York, NY: Viking, 2012. ISBN 978-0-670-02356-2. Maps. Notes. Sources Cited. Index. Pp. xxi, 234. \$26.95.

Veteran journalist Ahmed Rashid's latest offering is a mediocre contribution at best to the swollen river of books attempting to explain the myriad set of complex factors governing interactions between the United States, Pakistan, and Afghanistan. Following previous offerings by Rashid (Taliban and Descent into Chaos), this book rounds out a trilogy that offers more perspective into the author's viewpoints than into the actual issues themselves. Rashid makes many valid points regarding the topic, but to readers already familiar with U.S., Pakistani, and Afghan interactions, there are no new or particularly insightful nuggets for mining. His occasionally valid observations are outnumbered by diatribes that no one understands these issues or has any suitable solutions except for him. Placed in this context, the book has little value even for the novice, since the author's observations and analysis are often intertwined with his emotions and political biases.

According to Rashid, Pakistan has a host of foreign policy and domestic woes (both social and economic). He posits that U.S.-Pakistani relations have been steadily deteriorating over the last few years because there is no clear U.S. vision. He extrapolates that the same optimism generated by 2011's "Arab Spring" has not come to Central and South Asia, which are still plagued by religious and political extremism, as well as nuclear weaponry. His analysis is that everyone is to blame for this current state of affairs, especially former U.S. President George W. Bush (who, as the book unfolds is the scapegoat for all that is not right with the world).

Rashid undermines his own credibility early in the book by erroneously stating that factions affiliated and inspired by Usama bin Ladin (UBL) carried out the Khobar Towers bombing of June 1996 that killed nineteen U.S. Air Force members. In fact, it was perpetrated by an Iranian-backed Saudi Hizballah cell. The author correctly undertakes an examination of the lack of trust between Washington and Islamabad concerning UBL's multi-year presence in Pakistan. Bin Ladin breached Pakistani sovereignty for years by living undetected (or perhaps tolerated) in Pakistan. He then ponders whether the Pakistani army was culpable in hiding UBL 
or incompetent in not discovering his whereabouts. Given that Pakistan has social instability, terrorism, political violence, and economic volatility, it appears to be headed down the road to a failed state.

Placed in this context, Rashid asks how these factors will come into play if U.S. forces withdraw from Afghanistan in 2012. Given that the United States and Pakistan appear to have mutually exclusive equities in Afghanistan, a strengthening of radical Islamist factions in South and Central Asia may result.

Over ten years after the September 11, 2001 terrorist attacks, Afghanistan has not been rebuilt, the Taliban are militarily and politically viable, and South Asia is still unstable. Rashid complains throughout the book that no one in Washington can visualize or articulate the end state in Afghanistan or what the transition period will look like.

As he examines Pakistan, Rashid repeatedly engages in a great deal of second guessing and "if only" carping. If only Pakistan got along with its neighbors, if only Pakistan had a more stable and democratic process, if only Pakistan were more economically competitive, etc. He further complains that the United States has failed to hold Pakistan accountable over the last few years and that the Central Intelligence Agency's (CIA) activities in Pakistan have not been held to any standard of accountability.

Turning his attention to Afghanistan, Rashid begins to engage in blatant political tirades blaming former U.S. President George W. Bush and praising current U.S. President Barack Obama. He posits that Obama has been unable to move forward and is indeed trapped by the Bush legacy of failures. He also unleashes some of his invective on the U.S. military for not restoring order to Afghanistan. This unconcealed partisan rhetoric comes across like political campaign fodder rather than objective reporting. Rashid's bias towards Obama and disdain for Bush becomes shrill early on in the book and never lets up. His disgust for the U.S. military becomes strident in its expression. He puts forth his own set of values as he repeatedly criticizes the U.S. military. He further undermines his credibility by frequently using a Bob Woodward book as a primary source. He apologizes often for the Taliban and cites two different dates for the death of former U.S. diplomat Richard Holbrooke.

Rashid does accurately point out that the United States viewed its initial success of the Afghan campaign's dynamics and tried to mirror-image them onto Iraq. As both campaigns dragged on, the dynamics of the Afghan situation began to take on regional aspects. Rashid observes that "separately Pakistan and Iran wanted to ensure that when U.S. forces

132 
pulled out, they would shape the region's future. But the most dangerous source of instability was the escalation of the proxy war between India and Pakistan over future influence in Afghanistan" (130). As part of this process, Pakistan's Inter-Services Intelligence Directorate (ISI) has attempted to maintain control over U.S. and CIA contacts with the Taliban to influence the outcome in Islamabad's favor. Rashid correctly observes that Pakistan's efforts to control peace process discussions between the United States, Afghanistan, and the Taliban have not only reduced its influence in the region, they have made both regional and Western powers mistrust its intentions and good faith. Throughout the Afghan campaign, the ISI has played on both sides of the fence vis-à-vis the Taliban.

During the course of the book, Rashid comes across as a fawning celebrity name dropper as he recounts how he counseled U.S. President Barack Obama, Afghan President Hamid Karzai, and countless U.S. and foreign diplomats and senior military officers. His seemingly endless suggestions for how the United States should deal with Pakistan and Afghanistan ignore U.S. global security concerns in an age of transnational terrorism. His meandering prescriptions for U.S. global behavior are more rooted in the ephemeral realm of the intellectual idea fairy than the practical one of the strategist, policy maker, soldier, law enforcement officer, or intelligence analyst. However, in the midst of his philosophical musings, he does correctly observe that the United States must clarify the relationships it wants with Pakistan and Afghanistan and the region. He does, however, engage in selective perception when he urges Washington to initiate a dialogue with Tehran (Iran has rebuffed U.S. efforts to have a meaningful discussion of regional issues for many years).

For the discerning reader, Pakistan on the Brink holds little of value that cannot be found in better sources written by more objective observers. It is best left to lie fallow on the bookshelf. Like Rashid's other books, it will hit the discount bin soon enough.

Mark J. Roberts 
Journal of Strategic Security

https://digitalcommons.usf.edu/jss/vol5/iss4/5

D 0I: http://dx.doi.org/10.5038/1944-0472.5.4.11 
Roberts: Pakistan on the Brink: The Future of A merica, Pakistan, and Afgha

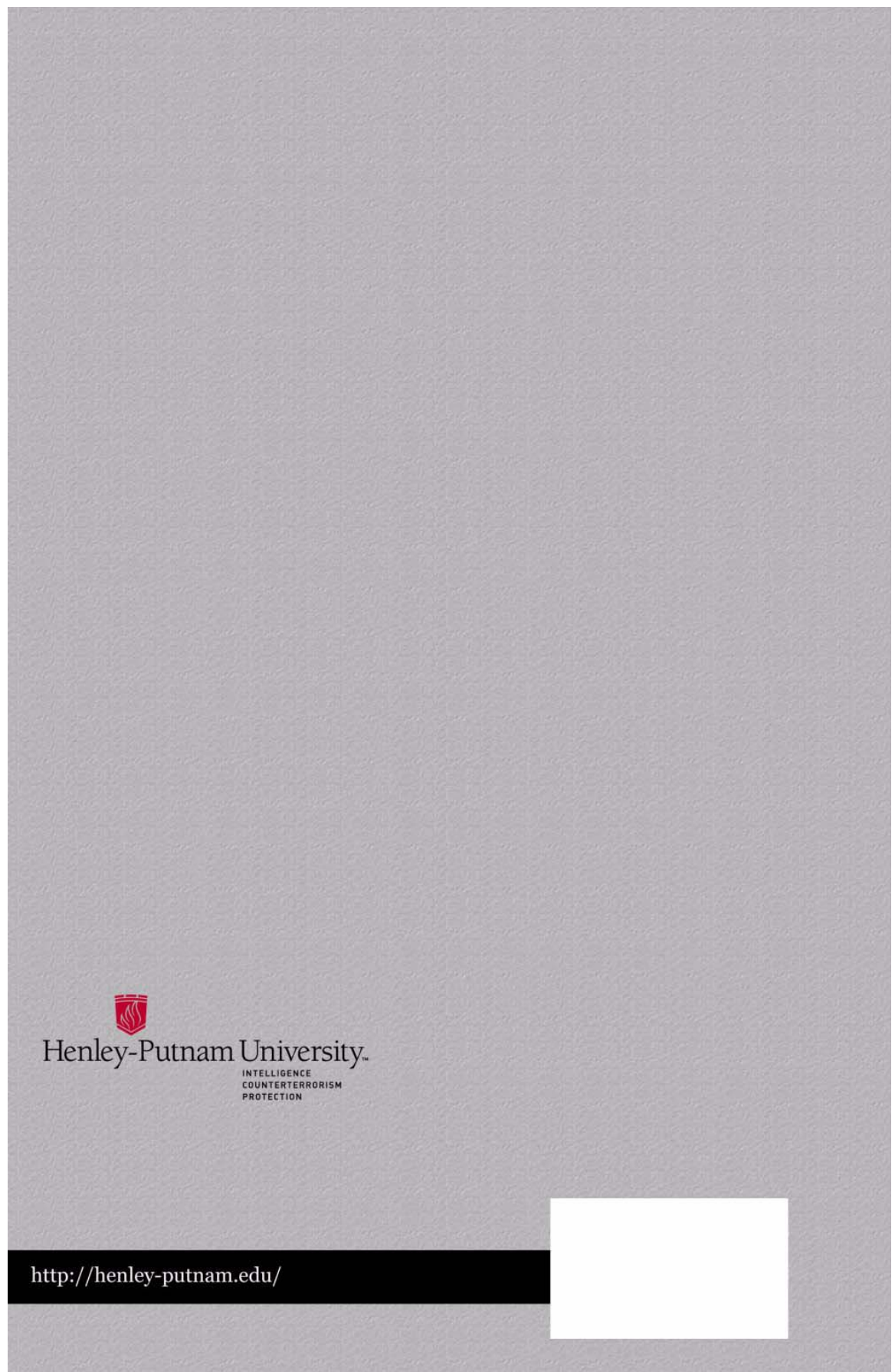

